\title{
Why is Inflation Targeting Adopted?
}

\author{
Yutaka Kurihara ${ }^{1, *}$ \\ 1Department of Economics, Aichi University, Japan \\ *Corresponding author: Department of Economics, Aichi University, 4-60-6 Hiraike \\ Nakamura Nagoya, 4538777, Japan. Tel: 81-52-564-6111. E-mail: kurihara@vega.aichi- \\ u.ac.jp
}

Received: March 16, 2020 Accepted: March 25, 2020 Published: March 26, 2020

doi: 10.5296/rae.v12i1.16679 URL: https://doi.org/10.5296/rae.v12i1.16679

\begin{abstract}
Since the early 1990s, inflation targeting (IT) has been conducted in many countries and the number of the countries has been increasing rapidly. The outcomes of adopting IT has been discussed, however, the incentives of adopting IT is not fully examined. This study focuses on this issue empirically. The results are clearly divided into two types of countries. In developed countries, budget/GDP ratio, central bank credibility, exchange rate stability, and openness of the economy are deterministic elements of adopting IT, however interestingly, inflation itself does not play any roles of adopting IT. On the other hand, only inflation is the deterministic element of adopting IT in developing countries. Other elements, that are deterministic elements in developed countries, do not any effects on introducing IT. Moreover, countries would not like to limit the scope of policies when the economy's openness is high.
\end{abstract}

Keywords: central bank, inflation targeting, budget, exchange rate, openness 


\section{Introduction}

Nearly 40 countries have adopted inflation targeting (IT) as their framework for monetary policy since the early 1990s. Countries that have adopted IT have, in general, shown good economic performance with stable inflation and economic growth. The effect of IT on the economies seems to be significant, and the number of countries utilizing IT is increasing.

Price stability is one of the most important tasks for policymakers in most countries, especially those in central banks, regardless of whether or not IT is adopted in reality. Several other frameworks, such as money targeting and exchange rate targeting, have been adopted to achieve price stability in many countries. Among these frameworks, IT has been used recently and has attracted a lot of attention. Since the 1990s, policymakers have become increasingly interested in inflation stabilization with the focus on reduction of inflation. The increased interest on inflation stabilization has contributed to the reduction of inflation rates from the high inflation rates experienced in the 1970s and 1980s when oil shock occurred by adopting IT. However, economic situations have changed. This paper examines why countries adopt IT. Many studies have been presented that provide evidence that the adoption of IT framework is associated with an improvement in overall economic performance (Bernanke \& Mishkin, 1997; Svenson, 1997; Svenson \& Woodford, 2005). Alternatively, very little research about the incentives of adopting IT has been conducted, and these should be examined alongside the economic performance. This study focuses on these incentives.

This study is structured as follows. Section 2 reviews recent discussion on IT. Section 3 presents a theoretical framework and an empirical method for the examination of why IT has been implemented. Section 4 shows the empirical results and analyzes them. Finally, a brief summary is provided.

\section{Which Countries Utilize IT?}

There are several definitions of IT. However, in general, IT is a policy framework by which central banks set the target rate for inflation publicly, and monetary policy is conducted according to this target (Fountas, Karanasos, \& Kim, 2002; Kurihara, 2003).

IT is a recently developed monetary policy framework. The United States has not yet implemented IT. The Bank of Japan (BOJ) also has not adopted this framework. The European Central Bank (ECB) does not admit the existence of IT, however, IT might be substantially conducted. Table 1 shows countries that conduct IT. 
Table 1. Countries That Conduct IT

\begin{tabular}{lccccc}
\hline \multicolumn{1}{c}{ Country } & Date & $\begin{array}{c}\text { Target at time } \\
\text { of adoption }\end{array}$ & Country & Date & $\begin{array}{c}\text { Target at time of } \\
\text { adoption }\end{array}$ \\
\hline New Zealand & 1990 & $1-3$ & Philippines & 2002 & $4+/-1$ \\
Canada & 1991 & $2+/--1$ & Guatemala & 2005 & $5+/-1$ \\
United Kingdom & 1992 & 2 & Indonesia & 2005 & $5+/-1$ \\
Australia & 1993 & $2-3$ & Romania & 2005 & $3+/-1$ \\
Sweden & 1993 & 2 & Serbia & 2006 & $4-8$ \\
Czech Republic & 1997 & $3+/-1$ & Turkey & 2006 & $5.5+/-2$ \\
Israel & 1997 & $2+/-1$ & Armenia & 2006 & $4.5+/-1.5$ \\
Poland & 1998 & $2.5+/-1$ & Ghana & 2007 & $8.5+/-2$ \\
Brazil & 1999 & $4.5+/-2$ & Uruguay & 2007 & $3-7$ \\
Chile & 1999 & $3+/-1$ & Albania & 2009 & $3+/-1$ \\
Colombia & 1999 & $2-4$ & Georgia & 2009 & 3 \\
South Africa & 2000 & $3-6$ & Paraguay & 2011 & 4.5 \\
Thailand & 2001 & $0.5-3$ & Uganda & 2011 & 5 \\
Hungary & 2001 & $3+/-1$ & Dominica & 2012 & $3-5$ \\
Mexico & 2001 & $3+/-1$ & Japan & 2013 & 2 \\
Iceland & 2001 & $2.5+/-1.5$ & Moldova & 2013 & $3.5-6.5$ \\
Korea & 2001 & $3+/-1$ & India & 2015 & $2-6$ \\
Norway & 2001 & $2.5+/-1$ & Kazakhstan & 2015 & 4 \\
Peru & 2002 & $2+/-1$ & Russia & 2015 & 4 \\
\hline
\end{tabular}

Source: Annual Report on Exchange Arrangements and Exchange Restrictions, various years.

\subsection{IT Policy}

First, the realization of price stability, which provides an economic foundation, could be judged accurately without arbitrariness. By implementing IT, markets can easily and accurately evaluate the economic performance of central bank policies. Second, increased transparency of central banks' goals provides market accountability for the target and independence from the government. The transparency leads to soundness of the economy. Third, this framework can provide stability of the expected inflation rate as well as inflation rate itself. Targeting locks in the expectations of stable inflation, which reduces the inflationary influence of macroeconomic shocks (Svensson, 1997). Of course, there are pros and cons, and the benefits vary across countries, however, the effects of adopting IT have been evaluated highly in general as mentioned in the previous section.

There are a lot of studies that evaluate IT highly. Valera, Holmes, and Hassan (2018) found a reduction in inflation rates that could manage the inflation targets in the Philippines, South Korea, and Thailand. Coulibaly and Kempf (2019) showed that IT could have reduced inflation and volatility of inflation in 31 emerging countries. Dinabandhu and Debashis (2019) confirmed that IT promotes credibility of central banks in thirteen Asian countries. Divino 
(2018) showed that IT promotes no harm to the economy of developing and emerging economics. Ferreira and Lacerda (2019) confirmed that IT can lower inflation risk in Latin American economies that adopt IT.

Critical points have also been provided. As managing inflation using monetary base or exchange rate may be less effective, trust in a commitment to IT could be harmful, and inflation rate could be unstable and lead to economic instability. Second, if markets believe and give credibility for the target, there is some possibility of an increase in long-term interest rates. It would cause a decrease in investments and consumption and lead to recession. As such, side effects by adopting IT would appear. Third, suitable inflation (CPI or PPI, for example) cannot be easily selected with clear reasons. It varies between countries and when IT is adopted. Finally, there are limited previous examples in which a central bank adopted IT during deflation or low inflation rate periods, so precedent examples would not be helpful. However, this issue seems to be very important for recently developed countries.

Wang (2016) showed that adopting IT does not have a significant influence on the inflation level or the inflation volatility, but it can increase GDP per capita in CEE economies. Araujo, Araujo, and Fernando (2018) found that IT has not been effective in controlling inflation rates below the target rate in Brazil. Mariscal, Powell, and Tavella (2018) suggested that IT gains credibility over time, but when the inflation rate rises above the target level, the credibility suffers in Latin America. Tweneboah and Alagidede (2019) demonstrated that IT did not have a significant impact on inflation volatility.

Togcu and Ozturk (2015) showed that IT should be implemented with the fiscal policy in middle- and high-income countries. Brito, Carriere-Swallow, and Gruss (2018) indicated that countries with low transparency benefit from IT adoption. Diaz-Roldan, Ferrari-Filho, and da Silva Bichara (2019) showed that adoption of a adequate fiscal policy rule leads to rationalizing fiscal consolidation with IT. Moreira, Monte, and Abdala (2018) found that inflation deviation from the target level in Brazil was determined by commodity prices, nominal exchange rate, and economic performance.

\section{Theoretical Background and Empirical Method}

\subsection{Theoretical Background}

This paper examines why countries adopt IT. There are many aspects for a country to consider before deciding to adopt IT. It is easy to expect large differences in high inflationary developing countries and deflationary developed countries. So, it is important to investigate whether or not structural differences exist between countries that employ IT and those that pursue other policy frameworks. To explore these differences, this paper uses a probit model in which the dependent variable is a dummy that uses the value of one for those countries that use IT and zero for countries that do not. This analysis uses four variables, as described below, to determine which elements affect the possibility that IT is adopted.

IT is effective while maintaining fiscal (deficit) discipline, which is considered important for 
sound economic growth. Therefore, it should have a positive impact on introducing IT. Those that cannot manage fiscal debt adequately have no incentives to adopt IT. Increased transparency of central banks' policies, especially inflation target level, provides market accountability for the target and independence from the government. So, this variable has a positive coefficient for IT. Exchange rate stability is related to IT. It reduces the incentive to adopt IT, so the coefficient is assumed to be negative. Past inflation would have a positive relationship with introducing IT, and it seems to be an important incentive to adopt IT. However, past inflation is not related with introducing IT in countries under deflation or low inflation countries. Inflation is influenced by both foreign and domestic elements. Countries that are affected by foreign factors may not find any merit in introducing IT. For example, when the real exchange rate depreciates in a very open economy, the depreciation as an effect of rising import prices could be harmful for the economy seriously. In that case, policymakers would not like to allow inflation because they prefer the inflation rate to be more flexible. Making the rate of inflation flexible allows the exchange rate to change in a desired direction. However, when the inflation rate is too high, such as the situation of hyperinflation, this idea would not be acceptable. The basic equation (1) is estimated as follows:

$\mathrm{IT}=\alpha$ Budget to GDP $+\beta$ Central bank policy $+\gamma$ Exchange rate stability $+\delta$ Price $+\zeta$ Trade openness to GDP

\subsection{Data and Empirical Method}

Budget to GDP is the ratio of government surplus/deficit to GDP. Central bank policy is from IMD (World Competitiveness Ranking). It denotes executive opinion survey based on an index from 0 to 10 . Exchange rate stability denotes parity change from national currency to SDR. Price denotes consumer price index. Trade openness means export plus import to GDP. All of the data except central bank policy are from International Financial Statics from IMF.

The sample includes data from 1995 to 2018. Yearly data are used for estimation. Australia, Canada, Iceland, Israel, Japan, Norway, Sweden, and the UK are listed as developed countries. Also, Brazil, Chile, Columbia, Czech, Hungary, India, Indonesia, Korea, Mexico, New Zealand, Peru, Philippine, Poland, Rumania, Russia, South Africa, Thailand, and Turkey are used as developing ones.

The basic empirical method is Panel Least Squares. Along with this estimation method, Generalized Method of Moments (GMM) and Censored regression methods are employed. GMM can be considered to expand linear regression to allow using both non-normal stochastic and non-linear systematic components. It is a useful and broad scope of specifications that includes linear regression, logistic and probit analysis, and poisson specifications. Censored regression methods are employed when the dependent variable is only observed. For example, data on incomes above a specified level can be treated as top-coded to keep confidentiality. These estimation methods are used for the regression analyses of equation (1). 


\section{Results and Implications}

The regression results of equation (1) are in Table 2a. Also, Granger causality tests are performed. The results are in Table $2 b$.

Table 2a. Deterministic Elements of IT: Whole Countries

\begin{tabular}{lllll}
\hline & Panel Least Squares & $\begin{array}{l}\text { Generalized } \\
\text { Model }\end{array}$ & $\begin{array}{c}\text { Linear } \\
\text { Censored } \\
\text { (TOBIT) }\end{array}$ & normal \\
\hline C & $1.643^{* * *}$ & $1.643^{* * *}$ & $1.283^{* * *}$ \\
Budget to GDP & $(16.480)$ & $(16.480)$ & $(6.513)$ \\
& $0.011^{* * *}$ & $0.011^{* * *}$ & $0.028^{* * *}$ \\
Central bank policy & $(3.189)$ & $(3.189)$ & $(4.348)$ \\
& $0.029^{*}$ & $0.029^{*}$ & $0.074^{* * *}$ \\
Exchange rate stability & $(1.945)$ & $(1.945)$ & $(2.595)$ \\
& -0.048 & -0.048 & $0.557^{*}$ \\
Price & $(-0.598)$ & $(-0.599)$ & $(1.946)$ \\
& $-0.010^{* * *}$ & $-0.010^{* * *}$ & 0.008 \\
Trade openness to GDP & $(-5.386)$ & $(-5.387)$ & $(0.534)$ \\
& -0.005 & -0.005 & $-0.020^{* * *}$ \\
Adj.R-squared & $(-1.601)$ & $(-1.601)$ & $(-3.199)$ \\
Dispersion & 0.153 & & \\
F-statistic & & 0.162 & \\
Prob(F-statistic) & 23.557 & & \\
LR statistic & 0.000 & 117.785 & \\
Prob(LR statistic) & & 0.000 & \\
Avg. log likelihood & & & \\
\hline
\end{tabular}

Note. $* * *, * *$, and $*$ are significant at 1,5 , and $10 \%$ respectively. Parentheses are t-value (panel least squares) and z-statistic (generalized linear model and censored normal).

Table 2b. Pairwise Granger Causality Tests: Whole countries

\begin{tabular}{lcc}
\hline Null hypothesis & F-statistic & Prob. \\
\hline IT does not cause budget/GDP & 4.548 & 0.033 \\
Budget/GDP does not Granger cause IT & 3.094 & 0.079 \\
IT does not Granger cause central bank credibility & 1.689 & 0.194 \\
Central bank credibility does not Granger cause IT. & 1.959 & 0.162 \\
IT does not Granger cause exchange rate stability & 9.533 & 0.002 \\
Exchange rate stability does not Granger cause IT & 11.100 & 0.0009 \\
Price does not Granger cause IT & 10.079 & 0.002 \\
IT does not Granger cause price & 23.754 & 1. E-06 \\
Trade/GDP does not Granger cause IT & 2.462 & 0.117 \\
IT does not Granger cause trade/GDP & 0.594 & 0.441 \\
\hline
\end{tabular}


The results are almost as expected, however, some variables are not significant. Some results are inconclusive. It would be necessary to analyze depending on economic conditions. This study divides the countries into developed countries and developing countries. The empirical results that the same methods are employed for the cases of Table $2 \mathrm{a}$ and Table $2 \mathrm{~b}$ are shown in Table 3a, Table 3b, Table 4a, and Table 4b.

Table 3a. Deterministic Elements of IT: Developed Countries

\begin{tabular}{lccc}
\hline & Panel Least Squares & $\begin{array}{c}\text { Generalized Linear } \\
\text { Model }\end{array}$ & $\begin{array}{c}\text { Censored normal } \\
\text { (TOBIT) }\end{array}$ \\
\hline C & $1.384^{* * *}$ & $1.384^{* * *}$ & $1.384^{* * *}$ \\
Budget to GDP & $(8.197)$ & $(8.197)$ & $(8.313)$ \\
Central bank policy & $0.024^{* * *}$ & $0.024^{* * *}$ & $0.024^{* * *}$ \\
& $(4.315)$ & $(4.315)$ & $(4.376)$ \\
Exchange rate stability & $0.064^{* *}$ & $0.064^{* *}$ & $0.064^{* * *}$ \\
& $(2.600)$ & $(2.596)$ & $(2.633)$ \\
Price & $0.486^{*}$ & $0.486^{*}$ & $0.486^{* *}$ \\
& $(1.956)$ & $(1.956)$ & $(1.984)$ \\
Trade openness to GDP & 0.006 & 0.006 & 0.006 \\
& $(0.444)$ & $(0.444)$ & $(0.450)$ \\
Adj.R-squared & $-0.017^{* * *}$ & $-0.017^{* * *}$ & $-0.017^{* * *}$ \\
Dispersion & $(-3.161)$ & $(-3.161)$ & $(-3.206)$ \\
F-statistic & 0.097 & & \\
Prob(F-statistic) & & & \\
LR statistic & 5.634 & & \\
Prob(LR statistic) & 0.000 & & \\
Avg. log likelihood & & 0.321 & \\
\hline
\end{tabular}

Note. $* * *, * *$, and $*$ are significant at 1,5 , and $10 \%$ respectively. Parentheses are t-value (panel least squares) and z-statistic (generalized linear model and censored normal).

Table 3b. Pairwise Granger Causality Tests: Developing Countries

\begin{tabular}{lcc}
\hline Null hypothesis & F-statistic & Prob. \\
\hline IT does not cause budget/GDP & 3.165 & 0.076 \\
Budget/GDP does not Granger cause IT & 1.498 & 0.221 \\
IT does not Granger cause central bank credibility & 0.630 & 0.428 \\
Central bank credibility does not Granger cause IT. & 3.748 & 0.053 \\
IT does not Granger cause exchange rate stability & 7.247 & 0.007 \\
Exchange rate stability does not Granger cause IT & 10.414 & 0.001 \\
Price does not Granger cause IT & 10.644 & 0.001 \\
IT does not Granger cause price & 19.676 & $1 . \mathrm{E}-05$ \\
Trade/GDP does not Granger cause IT & 1.736 & 0.188 \\
IT does not Granger cause trade/GDP & 0.070 & 0.792 \\
\hline
\end{tabular}


Table 4a. Deterministic Elements of IT: Developing Countries

\begin{tabular}{lccc}
\hline & Panel Least Squares & $\begin{array}{c}\text { Generalized Linear } \\
\text { Model }\end{array}$ & $\begin{array}{c}\text { Censored normal } \\
\text { (TOBIT) }\end{array}$ \\
\hline C & $1.682^{* * *}$ & $1.682 * * *$ & $1.682^{* * *}$ \\
Budget to GDP & $(13.579)$ & $(13.579)$ & $(13.680)$ \\
& 0.005 & 0.005 & 0.005 \\
Central bank policy & $(1.253)$ & $(1.253)$ & $(1.262)$ \\
& 0.018 & 0.018 & 0.018 \\
Exchange rate stability & $(0.341)$ & $(0.340)$ & $(0.337)$ \\
& -0.100 & -0.100 & -0.097 \\
Price & $(-1.107)$ & $(-1.107)$ & $-0.009 * * *$ \\
& $-0.009^{* * *}$ & $-0.009 * * *$ & $(-4.471)$ \\
Trade openness to & $(-4.438)$ & $(-4.438)$ & -0.002 \\
GDP & -0.002 & -0.002 & $(-0.454)$ \\
Adj.R-squared & $(-0.451)$ & $(-0.451)$ & \\
Dispersion & 0.170 & & \\
F-statistic & & & \\
Prob(F-statistic) & 16.384 & & \\
LR statistic & 0.000 & & -0.561 \\
Prob(LR statistic) & & 0.000 & \\
Avg. log likelihood & & & \\
\hline
\end{tabular}

Note. ${ }^{* * *},{ }^{* *}$, and $*$ are significant at 1,5 , and $10 \%$ respectively. Parentheses are t-value (panel least squares) and z-statistic (generalized linear model and censored normal).

Table 4b. Pairwise Granger Causality Tests: Developed Countries

\begin{tabular}{lcc}
\hline Null hypothesis & F-statistic & Prob. \\
\hline IT does not cause budget/GDP & 0.003 & 0.956 \\
Budget/GDP does not Granger cause IT & 1.060 & 0.304 \\
IT does not Granger cause central bank credibility & 0.838 & 0.361 \\
Central bank credibility does not Granger cause IT. & 1.261 & 0.263 \\
IT does not Granger cause exchange rate stability & 0.041 & 0.839 \\
Exchange rate stability does not Granger cause IT & 0.081 & 0.839 \\
Price does not Granger cause IT & 12.774 & 0.0004 \\
IT does not Granger cause price & 0.009 & 0.925 \\
Trade/GDP does not Granger cause IT & 0.677 & 0.412 \\
IT does not Granger cause trade/GDP & 1.210 & 0.273 \\
\hline
\end{tabular}

Some of the results displayed in the tables, especially the Granger causality tests, are inconclusive, however, the results are almost clear. In developed countries, budget/GDP ratio, central bank credibility, exchange rate stability, and openness of the economy are deterministic 
elements of adopting IT, but inflation does not play any role in adopting IT. On the other hand, inflation is the only deterministic element of adopting IT in developing countries.

For the case of openness of the economy, the theoretical aspect does not bring certain results as discussed in section 2 of this study. The empirical results confer the minus coefficient (disincentive to adopt IT) for the case of developed countries. The results seem to fit well with the theoretical analysis. Countries would not like to limit the scope of policies when the economy's openness is high. The results of developing countries fit well with the regression analyses. Some results of developed countries are not conclusive. Past inflation impacts the incentives of introducing IT.

\section{Conclusions}

This study empirically examined the incentives of adopting IT. The results are almost robust and conclusive. For this issue, it is necessary to consider economic conditions. According to this idea, this paper divided the countries into two, namely, developed and developing countries. In developed countries, budget/GDP ratio, central bank credibility, exchange rate stability, and openness of the economy are deterministic elements of adopting IT, but inflation does not play important role of adopting IT. On the other hand, only inflation is the deterministic element of adopting IT in developing countries. Moreover, countries under high economic openness would not like to limit the scope of policies. These results are robust and as expected, however, taking these ideas would not achieve adequate economic performance. This issue would be necessary to be analyzed further and wider.

\section{Acknowledgments}

This study is supported by The NITTO Foundation.

\section{References}

Araujo, E., Araujo, E., \& Fernando, F. F. (2018). Macroeconomic performance in Brazil under the inflation targeting regime. Investigation Economica, 77, 72-101. https://doi.org/10.22201/fe.01851667p.2018.304.66400

Bernanke, B. S., \& Mishkin, F. S. (1997). Inflation targeting: A new framework for monetary policy? Journal of Economic Perspective, 11(2), 97-116. https://doi.org/10.1257/jep.11.2.97

Brito, S., Carriere-Swallow, Y., \& Gruss, B. (2018). Disagreement about future inflation: Understanding the benefits of inflation targeting and transparency. IMF Working Papers, $18 / 24$.

Coulibaly, D., \& Kempf, H. (2019). Inflation targeting and the forward bias puzzle in emerging countries. Journal of International Money and Finance, 90, 19-33. 
https://doi.org/10.1016/j.jimonfin.2018.09.003

Diaz-Roldan, C., Ferrari-Filho, F., \& da Silva Bichara, J. (2019). The performance of fiscal policy under an inflation targeting regime: What can be learned by the Brazilian fiscal rules? Metroeconomica, 70(1), 98-118. https://doi.org/10.1111/meca.12231

Dinabandhu, S., \& Debashis, A. (2019). Credibility of inflation targeting: Some recent Asian evidence. Economic Change and Restructuring, 52(3), 203-219. https://doi.org/10.1007/s10644-017-9224-3

Divino, J. A. (2018). What impact does inflation targeting have on the real economy of developing and emerging countries? Annals of Financial Economics, 13(3), 1-18. https://doi.org/10.1142/S2010495218500124

Ferreira, F. B., \& Lacerda, N. W. C. (2019). Inflation targeting and inflation risk in Latin America. Emerging Markets Finance and Trade, 55(11), 2389-2408. http://dx.doi.org/10.1080/1540496x.2018.1514297

Fountas, S., Karanasos, M., \& Kim, J. (2002). Inflation and output growth uncertainty and their relationship with inflation and output growth. Economics Letters, 75, 1607-1617. https://doi.org/10.1016/S0165-1765(02)00009-5

Kurihara, Y. (2003). Why do EU countries use inflation targeting? Global Business and Economics Review, 7(1), 74-84. https://doi.org/10.1504/GBER.2005.006921

Mariscal, R., Powell, A., \& Tavella, P. (2018). On the credibility of inflation-targeting regimes in Latin America. Economia, 18(2), 1-24.

Moreira, R. R., Monte, E. Z., \& Abdala, A. (2018). Inflation targeting and inflation deviation inertia: a study for Brazil based on the fractional integration approach. Journal of Applied Economics, 21(1), 67-83. https://doi.org/10.1080/15140326.2018.1526877

Svensson, L. E. O. (1997). Inflation forecast targeting: Implementing and monitoring inflation targets. European Economic Review, 41, 1111-1146. https://doi.org/10.1016/S00142921(96)00055-4

Togcu, C. T., \& Ozturk, S. (2015). Macroeconomic Effects of inflation targeting: Evidence from the middle and high-income countries. Theoretical and Applied Economics, 22(4), 105-112.

Tweneboah, G., \& Alagidede, P. (2019). Dollarization, inflation targeting, and inflationary dynamics in Ghana. Journal of African Business, 20(3), 358-375. https://doi.org/10.1080/15228916.2019.1581011

Valera, H. G., Holmes, M. J., \& Hassan, G. M. (2018). Is inflation targeting credible in Asia? A panel GARCH approach. Empirical Economics, 54(2), 523-546. https://doi.org/10.1080/13504851.2016.1223817

Wang, C. (2016). Does inflation targeting work well? Evidence from CEE countries. Acia Oeconomica, 66(3), 375-392. https://doi.org/10.1556/032.2016.66.3.1 


\section{Copyright Disclaimer}

Copyright for this article is retained by the author(s), with first publication rights granted to the journal.

This is an open-access article distributed under the terms and conditions of the Creative Commons Attribution license (http://creativecommons.org/licenses/by/3.0/). 